\title{
Türk Üniversite Öğrencileri Gözünde Suriye İmajı Üzerine Göstergebilimsel Bir Çalışma
}

\author{
DOI: 10.26466/opus.662744
}

\author{
* \\ Salih Gürbüz * \\ * Dr. Öğr. Üyesi, Necmettin Erbakan Üniversitesi, Güzel Sanatlar Fakültesi, Sinema-TV Bölümü, \\ Konya/ Türkiye

\section{Öz} \\ E-Posta: gurbuzsalih@hotmail.com \\ ORCID: $\underline{0000-0002-5690-8136}$
}

Günümüz dünyası gittikçe küçülmekte, kalabalıklaşmakta ve herkes gittikçe birbirine benzemektedir. Böyle bir ortam ve zamanda imaj farklı olmanın adı olmuştur. Farklılı ise tercih edilme, öne çıma, gelir yaratma kapasitesi, taraftar ve destekçi bulma, takipçi toplama ve güç gibi anlamlara gelebilir. Ancak imaj oluşturulması ve yönetilmesi emek ve zaman isteyen bir süreci zorunlu kular. Imajin kaybedilmesi ise anlık gelişen bir kriz durumunda oluşabilir. Ülkelerin imajları da bireylerin ve kurumların imajları gibi öne çıkmak adına oldukça önemlidir. Ülkelerin ekonomik ve politik süreçleri ülkelerin imajların olumlu ya da olumsuz olarak etkileyebilmektedir. Bu çalışma ile Türk öğrenciler nezdindeki Suriye imajının araştırılması amaçlanmıştır. Bu amaca yönelik, Resim Bölümü Lisans öğrencileri ile bir çalışma tasarlanmıştır. Öğrencilerin resimleri araştırmanın verileri olarak göstergebilimsel çözümleme ile değerlendirilmiştir. Çalışmanın sonucu olarak, öğrencilerin nezdinde Suriye imajl, savaş, ölüm, hüzün, belirsizlik, zorluklar, mă̆dur kadınlar, mağdur çocuklar, mutsuzluk, tutsaklık, güvensiz ülke, huzursuzluk, korku, şiddet, çaresizlik, umutsuzluk, kaos, acl, göç, yoksulluk, fiziksel ve finansal imkansızlık, kan, zulüm ve tehlike ifadeleri ile karşıllk bulduğu değerlendirilmiştir

Anahtar Kelimeler: ̇maj, Ülke imajı, Suriye, Suriye imajı, üniversite öğrencileri 


\title{
A Semiotic Study On Syria Image in the Eyes of Turkish University Students
}

\begin{abstract}
Today's world is getting smaller and crowded and everyone is more and more alike. In such an environment and time, the image term has become the name of being otherness. Otherness can mean being prefered, prominence, income generation capacity, finding fans and supporters, gathering followers and power. However, image creation and management necessitates a process that requires time and effort. Loss of the image can occur in the event of a instant crisis. The country image are very important to be distinguished like the images of individuals and institutions. The economic and political processes of the countries can affect the images of the countries positively or negatively. The aim of this study was to analsyis the image of Syria among Turkish students. For this purpose, a study was designed with undergraduate students of the Department of Painting. The students' paintings as the data of this study were analyzed with semiotic analysis. As a result of the study, Syrian image were evaluated with the terms as war, death, sadness, uncertainty, difficulties, victimized women, victimized children, unhappiness, captivity, insecure country, uneasiness, fear, violence, helplessness, hopelessness, chaos, pain, migration, poverty, physical and financial impossibility, blood, cruelty and danger.
\end{abstract}

Keywords: Image, country image, Syria, Syrian image, university students 


\section{Giriş}

Günümüzde hem bireyler hem de kurumlar açısından yaşamsal bir değerle karşılık bulan imaj kavramı insanların zihinlerinde herhangi bir konu, nesne, kişi ya da kurum hakkında oluşan düşünceler ya da görüntüler olarak tanımlanabilir. Bireyler gibi kurumların ve kurumsal yapıya sahip olan ülkelerin de imajları vardır. Gündelik hayatta yaşanan gelişmeler ve uluslararası ortamlarda meydana gelen her türlü siyasi, ekonomik, sosyal ve kültürel olaylar ülkelerin diğer ülke insanları üzerindeki imajlarını olumlu ya da olumsuz yönde etkileyebilmektedir. Ülkelerin sahip olduğu imajlar ise o ülkenin diğer ülke vatandaşları nezdinde hem zihinsel hem de duygusal anlamda onaylanmasına ya da onaylanmamasına sebep olabilir. Herhangi bir ülkenin vatandaşları nezdinde onay alan, kabul gören, olumlu düşünce ve duygularla hatırlanan ve imgelenen ülkelerin imajları o ülkenin insanları hakkında da sahip olunan ya da olunabilecek algılara da etki edebilir. Bir diğer ifadeyle ülke imajı ülke halkının ya da ülke halklarının da imajı da olabileceği değerlendirilebilir. Günümüz ülkelerinin yapısı itibarıyla ülke imajları ulus imajları olarak da değerlendirilebilir.

Günümüzde bir ülkede yaşanan çok çeşitli olaylar ve gelişmeler hem kitle iletişim araçlarının sunduğu olanaklarla hem de önemli bir haber ve iletişim mecrasına dönüssen ve o şekilde kullanılan sosyal medya ortamları üzerinden anlık olarak dünyanın diğer ülkelerinde yaşayan tüm bireylere ulaşabilmektedir. Bilginin ve iletişimin bu şekilde hızlı dolaşımda olduğu günümüz dünyasının bireyleri artık sadece kendi ülkelerinde yaşanan gelişmeleri değil diğer ülkelerdeki yaşanan gelişmeleri de takip eder olmuştur. Hatta bu takip etme bir bilinçlilik düzeyinde kendini gösterebilmektedir. Bireylerin bu isteklerinin karar ve eyleme dönüşmesinde ise o ülke hakkında çeşitli mecralardan elde ettikleri bilgiler neticesinde oluşturdukları algılar yönlendirici olabilmektedir.

Diğer ülkeler hakkında bilgi sahibi olmanın çeşitli motivasyonları olabilir. İnsanların başka ülkelere seyahat etme, o ülkelerde yaşama, o ülkelerin sağlik ve eğitim olanaklarından yararlanma gibi istekleri bireylerin kendi ülkeleri dışındaki ülkeler hakkında bilgi sahibi olmaları yönünde teşvik edici etmenler arasında sıralanabilir. Tabii ki insanların başka ülkeler hakkında bilgi edinme arayışları sadece bu sıralamada ifade edilmeye çalışılan etmenlerle sınırlandırılamaz. Ancak teknolojinin iletişime olan büyük katk1- 
ları ile bireyler dünyanın içinde tek ülkede yaşıyormuş gibi değerlendirilebilmektedir. Böyle bir dünyada insanlar başka ülkeler hakkında kasıtlı ve isteyerek ya da istem dışı şekil ve araçlar yoluyla sürekli bilgilere maruz kalabilmekte ve bu süreçte başka ülkeler hakkında bireylerin zihninde imaj üretimleri ile karşlık bulabilmektedir.

Ülke imajları da kurumsal ve kişisel imajlar gibi oluşturması, yönetmesi ve korunması zor ancak yıkılması ve olumsuza dönüşmesi ise anlık gelişen olaylara bağlı olacak kadar da kolaydır. Özellikle kurumları tehdit eden krizler gibi ülkeleri de tehdit eden gelişmeler ülkelerin imajlarına zarar verebilmektedir. Özellikle ekonomik kaygılar ve çımazlar üzerine temellendirilen günümüz ülkelerinin karşı karşıya kaldığı krizler halkın meydanlarda toplanarak hükümetlerin politikalarını protesto etme şeklinde kendini gösterebilmektedir. Yakın zamanların en güncel meseleleri olan Arap Baharı ve Amerikan Baharı adlandırılmaları ile anılan çeşitli eylemler dünya kamuoyunca medya araçları üzerinden takip edilmiş, hatta bireyler takibinde ötesine geçerek bu meselelere sosyal medya ortamlarından katılım sağlayarak kendi ülkelerinin meseleleriymiş gibi görüşler ortaya koyma eğilimleri ve davranışları da göstermişlerdir. Farklı ülkelerin vatandaşlarının dünyanın çok farklı ülkelerinde meydana gelen gelişmeleri bu kadar yakından takip etmeleri gerçeği ülke imajlarının ne kadar da yönetilmesi önemli bir konu olduğuna işaret olarak ifade edilebilir. Son zamanlarda ise Fransa'da yaşanan "sarı yeleklilerin protestoları" şeklinde medyada adlandırılan ve farklı ülkelere de yayılan gösteriler oldukça yeni bir örnektir. Bu ve buna benzer örneklerin Türkiye'deki insanların da gündeminde önemli yeri olduğu düşünüldüğünde, Türkiye'deki bireyler üzerinde Fransa hakkında çeşitli algıların oluşmasına kaynak olarak görülebilir. Öyle ki bu tür durumlarda hem Türkiye hem de diğer ülkelerin dış işleri bakanlıkları kendi ülke vatandaşlarını uyarma gereksinimi dahi duyarak medyada mesajlar yayınlayabilmektedir. Tüm bunlar bireylerin başka ülkeler hakkındaki imajlarına olumsuz yönde etki edebilmektedir.

Başka bir bakış açısıyla ülke imajı konusu değerlendirildiğinde ise; ülkeler imajlarını onarmak ya da imajlarını korumak amacıyla da stratejik çalışmalar yürüterek kendi ülkeleri hakkında tanitım filmleri ve tanitım günleri gibi etkinliklerle diğer ülke vatandaşları nezdinde olumlu imaj oluşturma çabaları da yürütebilmektedir. Türkiye Cumhuriyeti Kültür ve Turizm Ba- 
kanlığı'nın her yıl yenilediği tanıtım filmlerinin farklı ülkelerin medyalarında yayınlanıyor olması da buna bir örnek olarak ifade edilebilir.

Ülke imajlarının yönetilmesi ülkelerin uluslararası ortamlarda ekonomi başta olmak üzere çok çeşitli alanlarda firsatlara sahip olabilme amaçları bakımından oldukça önemli bir konudur. Bu çalışma özelinde de 2011 yıl1nın bahar aylarında başlayan Suriye iç savaşı ve ardından gelişen göç olayları ile birçok ülke Suriye hakkında konuşur olmuş ve Suriye iç savaşı birçok ülkenin de iç meselesi haline de dönüşmüştür. Suriye iç savaşı en çok da Türkiye'yi ve Türk insanının gündeminde yer bulmaktadır. Dünya ülkeleri arasında en çok sığınmacı göçünü alan Türkiye Cumhuriyeti vatandaşları Suriye göçünün getirdiği çok çeşitli sorunlarla karşı karşıya kalmıştır. Hemen hemen her şehir ve ilçede hatta bazı bölgelerde köylerde dahi yaşayan Suriyeli sığınmacılarla karşılaşmak mümkündür. Her bir Suriyeli sığınmacı, yaşadığ1 göç ile birlikte kendi ülkesinin kültürünü oluşturan çok çeşitli unsurları da yanında taşımaktadır. Haliyle geldikleri ve yerleştikleri yerlerde de hem kendileri hem de kendileriyle ilişki içerisinde olan yerel halk başlıca ekonomik, sağlık ve eğitim alanlarında sorunlarla yaşamaya başlamıştır. $\mathrm{Bu}$ yaşanan sorunlar ise akademik çevrenin şüphesiz üzerine çalışmalar yapması gerekliliğini de ortaya çıkarmıştır. Suriyeli sığınmacılar hakkında çok çeşitli disiplinlerden birçok akademik yayın türü de ortaya konmaktadır.

Halkla ilişkiler açısından Suriyeli imajına yönelik ortaya konan çalışmaların olduğu ancak çok sınırlı olduğu dikkat çekmektedir. Suriyeli imajına yönelik yapılan çalışmaların nicel veri toplama yöntemi olan anketlerle ve nitel yöntemlerden görüşme formları üzerinden gerçekleştirildiği de ayrı bir değerlendirme olarak ifade edilmelidir. Ancak bu çalışma Suriyeli imajından farklı olarak Suriye ülke imajı üzerine odaklanılmasını amaçlanmıştır. Özellikle iç savaş sonrası Türkiye'de Suriye ülke imajına yönelik çalışmaya rastlanamamıştır. İç savaştan önceki süreçte de Suriye imajına yönelik herhangi bir çalışmanın da yapılmamış olduğu da ayrıca değerlendirilmiştir. Bu çalışma ile gündelik yaşam pratikleri içinde Suriyeli sığınmacılarla iç içe yaşayan ve Suriye iç savaşı hakkında medyada yer alan haberlere sürekli maruz kalan yerel halkın zihnindeki Suriye imajının nasıl olduğu ortaya konmaya çalışılacaktır.

$\mathrm{Bu}$ çalışma ile sanatsal eserlerin bilimsel sonuçlara ulaşmada veriler sağlayabileceği düşüncesinden hareketle, Suriye ülke imajı Suriyeli nüfusun oldukça yoğun yaşadığı kentlerden biri olan Konya ili, Necmettin Erbakan 
üniversitesi Güzel Sanatlar Fakültesi Resim Bölümü öğrencilerinin eserleri üzerinden değerlendirilmeye çalışılmıştır. Bu amacı gerçekleştirmek için Resim Bölümü 2019-2020 akademik yılı güz döneminde öğrenim gören Sanat Sosyolojisi dersini alan 27 ikinci sınıf öğrencisi ile çalışma yürütülmüştür. Çalışma gerçekleştirilirken sanat sosyolojisi dersi alan öğrencilerle sınırlandırılma yapılmasının temel dayanağı, sanat sosyolojisinin sanatla sosyal yapı arasındaki ilişkileri araştırması kabulüdür (Erinç, 2013, s.55). Ayrıca Çağan'ın (2006, s.13) sanat, insani ve toplumsal varoluşa ilişkin çok çeşitli görünümün bilimsel metinlerde bulunamayacak en canlı temsilini, bilinçaltını, dip akıntısını, diğer bir anlamda en gerçek yüzünü barındırabileceği şeklindeki ifadesi de bu anlamda önemli görülebilir. Bu nedenle sanat eserinin ve sanatçının sosyolojik anlamda incelenmesini amaçlayan sanat sosyolojisi eğitimleri ile sanat çalışmaları yapan öğrencilerin hem yerel hem de ulusal ve uluslararası gündemlere olan aşinalıklarının daha belirgin olabileceği öngörülmüştür. Böylece katılımc öğrencilere Suriye ülke imajı hakkında ne düşündüklerini resmetmeleri istenmiştir. Bir aylık bir süre tanınan öğrenciler çalışmalarını 1-30 Kasım 2019 tarihleri arasında tamamlamışlardir.

\section{İmaj ve Ülke İmajı}

Kişiler ve kurumların birbirleriyle yarış içinde olduğu dünyada, imaj kavramı hem bireyler hem de kurumlar açısından oldukça önemlidir. Herhangi bir canlı ya da cansız obje hakkında bireylerin zihinlerinde oluşturdukları kanı, düşünce ve görüntü olarak tanımlanabilen imaj yönetilmesi zorunlu olarak görülen bir anlama sahiptir. En genel tanımıla imaj, herhangi bir kişi, kurum ya da durum hakkında görüşlerin toplamıdır (Peltekoğlu, 2014, s.571). Vural ve Bat'ın tanımında (2013, s.121) imajın kişisel becerilerin ve kişiyle ilişkili olan tüm algıların toplamı olduğu ifade edilmektedir. Linkemer' in $(1997$, s.13) tanımında ise izlenim kavramına vurgu yapılarak, bireylerin gördüğü ve algıladığı diğer bireyler ve kurumlara yönelik oluşturdukları izlenimlerin toplamı olduğuna dikkat çekilir. Yazıcı ise (1997, s.17) imajin bir anlam olduğunu, sembolünde bu anlamı yaratan bir gösteren olduğunu ifade etmektedir. Anlamın imaj da gizli olduğuna işaret edilmektedir.

Bir ülke hakkında bireylerin genel tutumlarını yansıtan ülke imajı, ülkelerin sahip olduğu teknoloji, eğitim sistemi, kültürel ve politik yapıları gibi 
çeşitli unsurlardan kaynaklanan algılar olarak ifade edilebilir. Bir tanımda ise ülke imajının insanların belirli yerler hakkındaki sahip oldukları inanç ve izlenimlerin toplamı olduğuna işaret edilmektedir (Martinez ve Alvarez, 2010, s.749). Ülke imajinın kompleks bir yapıya sahip olduğu ifade edilmektedir. İmajın inançlarla ilişkili olan bilişsel (algısal) ve duyguları kapsayan duygusal olarak iki tür değerlendirilmesi yapılmaktadır. Bilişsel değerlendirmeler bir yerin nitelikleri hakkındaki inançlara ya da bilgilere atıfta bulunurken, duygusal değerlendirme ise o yere ilişkin duygulara ya da o yere olan bağlllık anlamında ifade edilmektedir. Bir yerin genel imajı o yerin hem bilişsel hem de duyuşsal değerlendirmelerinin bir sonucu olarak oluşabilmektedir (Baloglu ve McCleary, 1999, s.870). Castro vd. (2007, s.177) yapılan bir çok çalışmada bir yere ait olan imajın değerlendirilmesinde bilişsel unsurun duyuşsal unsurdan daha önde olduğuna yönelik kantların olduğuna dikkat çekmektedir. Ancak Beerli vd.'nin (2002, s.486) üniversite öğrencilerine yönelik yaptığı çalışmada bireylerin imaj oluşturmalarında duyuşsal unsurun daha güçlü olduğu ortaya konulmaktadır. Bununla birlikte duyuşsal ve bilişsel her iki unsurunda öğrencilerin üniversite hakkındaki imajlarını anlamlı bir şekilde etkilediği de değerlendirilmektedir. Özetle ifade edilecek olursa, Yuille ve Catchpole (1997, s.171) imajin fikirlerden, duygulardan ve önceki deneyimlerden kaynaklanan ve bunların hatırlanarak zihinsel imgelere (resimlere) dönüştürüldüğü bir süreç olduğuna vurgu yapmaktadır. Bakan ve Tabakçı ise $(2008$, s.98) ülke imajlarının bilinmesinin ve yönetilmesinin eğitim, kültür, askeri vb. çeşitli alanlardaki ilişkilerin düzenlenmesinde önemli rol oynayabileceğini değerlendirmektedir. Ayrıca Bakan (2013,s.269) olumlu bir imajın, ülkenin uluslararası ortamlarda güçlenmesine ve olumlu imaj geliştirmenin ülkelere rekabet avantajları sağlayabileceğine dikkat çekerek ülke imajının önemini ifade etmektedir.

\section{Suriyeli İmaj ve Tutumlarına Yönelik Çeşitli Çalışmalar}

Bu başlık altında Suriyeli imajına (algısına) yönelik Türkiye'deki akademik yazında çeşitli disiplinlerde ortaya konan çalışmalardan bazılarına yer verilecektir. Doğrudan Suriye ülke imajına ilişkin çalışmanın ne Suriye iç savaşı öncesinde ne de sonrasındaki süreçte Türkiye akademik literatüründe ortaya konmamış olması da bu çalışmanın Suriyeli algılarına yönelik yapılan çalışmaları inceleme zorunluluğuna sevk etmiş ve bu bağlamda bir izlek 
geliştirme çabalarına yön vermiştir. Bu nedenle bu çalışmanın bilimsel düşünce zeminini oluşturması bakımından "Suriyeli algısına" yönelik çalışmalardan literatür anlamında yararlanma zorunluluğu ortaya çıkmıştır. Giriş bölümünde araştırmacı tarafından ortaya konan düşüncede bir ülkenin halkı hakkında sahip olunan algıların o ülkenin kendi imajına da karşılık gelebilme ihtimali tartışmaya açılmıştır. Ancak böyle bir iddia da bulunulmadığı özellikle vurgulanmalıdır. Çünkü ülke hakkındaki imajlarla ülke vatandaşları hakkındaki imajların farklı olma olasılığının tartışmaya işaret eden düşünceden çok daha fazla olabileceği kanısı özellikle ifade edilmelidir. Bu bakımdan bir ülkenin imajını araştırma çabasına katkı sağlayabileceği düşüncesinden hareketle, ülke imajına yönelik ihtimal dahilinde öngörülen işaret/lerin tespit edilebileceği kaygisı ile Suriyeli algılarına yönelik çalışmaların önemli olduğu değerlendirilerek burada yer verilmek istenmiştir.

Özellikle Türkiye'deki üniversitelerin çeşitli bölümlerinde öğrenim gören öğrenci örneklemlerinde gerçekleştirilen çalışmalara ait bulgulara daha çok yer verilmeye çalışılmıştır. Bu çalışmanın da üniversite öğrencileri ile yürütülmesi bakımından, Suriyeli imajının Türkiye'deki öğrenciler nezdinden hangi anlamlara geldiğini ortaya koymak bakımından literatürün bu çerçevede araştırılması da bu çalışmanın diğer önemli boyutu olarak ifade edilebilir.

İzmir ili Dokuz Eylül Üniversitesi Kamu Yönetimi bölümü öğrencileri ile yapılan bir çalışmada, öğrencilerin Suriyeli sığınmacılara yönelik tutumları incelenmiştir. Buna göre, Suriyeli arkadaşı olan öğrencilerin Suriyeli sığınmacılara karşı tutumlarının daha olumlu olduğu, öğrencilerin ailelerinin Suriyelilere karşı tutumlarının olumsuz olmasının da tutumları olumsuzlaştırdığ1 değerlendirilmiştir (Şen ve Şimşek, 2019, s.1958). Ayrıca öğrencilerin vatandaşlık verilmesi, güvenlik tehdidi oluşturması, toplumun sağlığına olumsuz etkilemesi, işsizlik ve Suriyelilere yönelik pozitif ayrımcılık yapan haklardan yararlanmaları gibi konularda olumsuz tutumlara sahip oldukları da araştırmada ifade edilmiştir. Bununla birlikte Türk kültürüne uyum sağlamaları, eşit sağlık hizmetlerinden yararlanmaları, onlara karşı negatif ayrımclık yapılmaması gibi konularda da olumlu tutum ortaya koyduklarına yönelik bulgulara yer verilmiştir (Şen ve Şimşek, 2019, s.1970).

Üniversite öğrencilerinin Suriyelilere yönelik algıları hakkında yapılan başka bir çalışma ise, Ankara Yıldırım Beyazıt Üniversitesinin edebiyat, psikoloji, sosyoloji ve siyasal bilimler bölümlerinde öğrenim gören öğrenci- 
lerle görüşme tekniği ile gerçekleştirilmiştir. Araştırmada duygu, düşünce, davranış gibi alt başlıkları olan "tutum" ve ekonomi, kültür ve çözüm önerileri alt başlıklarından oluşan "mültecilerin varlığının doğurguları" başlıklı iki tema oluştuğu ifade edilmiştir. Araştırmacılar duygu alt başlığında acıma ve üzüntü, düşünce alt başlığında çocuklara karşı olumlu tutumlar, davranış alt başlığında çocuklara ayrıcalıklı davranma, kötü davranışta bulunmama, yardım etme ve hoşgörülü davranma gibi ifadelerin ön plana çıktığına yönelik bulgulara yer vermişlerdir. Ayrıca katılımcıların Suriyelilerle daha az etkileşimde bulunmayı ve Suriyeli erkeklere mesafeli oldukları davranışlarına dikkat çekilmiştir. Mültecilerin varlığının doğurguları temasına göre de, ekonomi alt başlığında Suriyelilerin ucuz işçi probleminin ve işsizliğin kaynağı olduğu, ekonomik yük oldukları; kültür alt başlığında dil, uyum, tarihi ve geçmiş farklılıklar, çok eşlilik, yüksek doğum oranları ve kültür çatışmaları ön plana çıkan konular olduğu vurgulanmıştır. Araştırmacılar, katılımc öğrencilerin çözüm önerisi alt başlığında eğitim, aile planlaması ve çift taraflı oryantasyon konuların önemli gördüklerini ifade etmiştir (Aslan vd., 2018, s.486).

Polat ve Kaya $(2017$, s.38) tarafından yapılan çalışmada Suriyelilere yönelik ötekileştirmenin nasıl inşa edildiği konusu Adana ilinde yaşayan üniversite öğrencileri ile yapılan görüşmelerle araştırılmıştır. Çalışma bulguları arasında göç deneyimi yaşamış olan üniversite öğrencilerin ötekileştirme pratiklerini daha az kullandıkları ve sığınmacıların öncelikle insan haklarından yararlanması ve yaşaması gereken insan topluluğu olarak değerlendirildiği vurgulanmıştır. medyanın ötekileştirmede rolünün belirgin olduğu da çalışmanın bir diğer bulgusu olarak sunulmuştur. Türkiye'de medya unsurlarının Suriyeliler konusunda hedef gösterici bir tutumda olduğuna işaret edilmiştir. Suriyelilere yönelik sinurlı ve olumsuz tutumlara işaret eden algıların varlığı da ayrı bir bulgu olarak değerlendirilmiştir. Araştırmanın diğer bulguları ise birlikte yaşama isteğinin olmadığı, Suriyelilerin güvenlik sorunu yarattıkları, vatandaşlık hakkı vermek yerine insani ve etik koşulları içeren politikaların sığınmacıların lehine olacağı, ortak din bağına rağmen kaynaşmanın olmadığı şeklinde sıralanmıştır (Polat ve Kaya,2017, s.46).

Sağır ve Kurtakara (2018) tarafından yapılan bir araştırma da Sosyoloji bölümü öğrencilerinin Suriyeli kavramına ilişkin tutumları değerlendirilmiştir. Araştırmacıların elde ettiği sonuçlara göre, sosyoloji öğrenimi gören 
katılımcıların Suriyelilere yönelik tutumları sığınmaciların topluma uyum sağlayamadıkları, Suriyelilerin toplumda yeni problemlerin kaynağı olarak görüldüğü, katılımcıların Suriyelilere vatandaşlık verilmesini kesinlikle kabul etmedikleri, sığınmacıların temel ihtiyaçlarını karşılayamadıkları konusunda katılımcıların hem fikir oldukları şeklinde sıralanmaktadır (2018, s.661).

Üniversite öğrencilerine yönelik bir başka çalışmada da katılımcıların çoğunun Suriyelilerin Türkiye'deki üniversitelere erişimi konusunda ciddi endişeleri olduğunu ortaya koymaktadır. Ancak Suriyeli sınıf arkadaşlarının sınıflarına katılımını da desteklediklerine yönelik bulguların olduğuna dikkat çekilmektedir (Ergin, 2016, s.399).

Üniversite öğrencileri ile gerçekleştirilen bir diğer çalışmada da öğrencilerin sığınmacılar hakkındaki olumsuz düşüncelere katıldıkları, sığınmacılara yönelik üretilebilecek radikal ve ılımlı çözüm önerileri konusunda ise kararsız kaldıkları, ancak sığınmacı haklarını savunan ifadelere katıldıkları şeklinde bulgulara yer verilmiştir (Çimen ve Quadır, 2018, s.1251).

Sönmez ve Adıgüzel'in (2017, s.797) Gaziantep şehri örneğinde anket ve mülakalat yöntemleri ile gerçekleştirdikleri çalışmalarında Suriyeli sığınmacıların varlığını olumsuz değerlendiren katılımcıların oranı \%45 civarında olduğu ifade edilmiştir. Ayrıca araştırmacılar, çalışmada şehrin en önemli sorunu olarak Suriyeli sığınmacılar konusunun, şehrin çevre kirliliğii, ekonomik sorunları, güvenlik ve altyapı gibi diğer sorunlarından daha önemli görüldüğünü bulgularında tartışmaktadır. Ancak araştırmacılar Suriyeli sığınmacılara yönelik olan olumsuz algının yaşanmışlıktan ziyade genel kanılarla ilişkili olduğunu yapılan görüşmelerden elde ettikleri bulgularla ortaya koymaktadır. Bu olumsuz algının kaynağı olarak da ekonomik ve kültürel kökenli sorunları işaret etmektedirler (Sönmez ve Adıgüzel, 2017, s.804-806).

Kemik vd. (2019, s.582) tarafından Suriyeli sığınmacı nüfusun yoğun olarak yaşadığı ifade edilen Ankara'nın Altındağ bölgesindeki Türk kadın katılımcılarla görüşme tekniği ile bir çalışma gerçekleştirmişlerdir. Buna göre, Türk katılımcıların Suriyeliler hakkında yanlış ve abartılı görüşlere sahip olduğu, olumsuz tutumlara sahip oldukları, yasal düzenlemeler ve verilen haklarla ilgili yeteri düzeyde bilgilerinin olmadığı değerlendirilmiştir. 
Çiftçi'nin (2018, s.2232) Türkiye'de yedi coğrafi bölgedeki vatandaşlar ile gerçekleştirdiği çalışmaya göre; Türkiye Cumhuriyeti vatandaşlarının Suriyelilere önyargılı olmadıkları, sığınmacılara çalışma hakkı verilmesi ve suça meyilli olmamaları konularında olumlu algıya sahip oldukları, ancak Suriyeli sığınmacılara vatandaşlık hakkı tanınması, birlikte yaşama ve empati kurma konularında olumsuz algılara sahip oldukları değerlendirilmiştir.

Suriyelilere vatandaşlık verilmesi hakkında yerel halktan ve Suriyeli s1ğınmacılardan oluşan katılımcılarla mülakat tekniği ile yapılan bir çalışmada Türk halkının büyük çoğunluğu vatandaşlık verilmesine karşı oldukları$\mathrm{n}$ belirtmiştir. Bunu da milliyet unsuruna, Suriyelilerin neden olduğu düşünülen çeşitli sorunlara, vatandaşlık ile Türkiye'de temelli kalabilecekleri endişesine ve ekonomik olarak yük oldukları gerekçelerine dayandırdıkları da çalışmada ifade edilmiştir (Gülyaşar, 2017, s.678).

Bu başlık altında literatürde ortaya konan Suriyeli imajına (algisına) yönelik çalışmalarda hem öğrencilerin hem de toplumun diğer demografik özelliklerine sahip olan bireylerin olumsuz algı ve tutumlara daha çok sahip oldukları değerlendirilmesi yapılabilir.

\section{Yöntem}

Halkla ilişkiler literatüründe ve çeşitli disiplinlerde araştırmacılar tarafından Suriyeli algısına yönelik yapılan nicel ve nitel çeşitli çalışmalar olmakla birlikte, Türk katılımcılar nezdinde Suriye ülke imajına yönelik çalışmalara rastlanamamıştır. Suriye iç savaşı sonrası Türkiye'ye 4 milyon gibi önemli bir nüfus sığınmacı olarak gelmiş ve bu insanlar Türkiye'nin birçok şehrinde yerel halkla iç içe yaşamaya başlamıştır. Böyle bir ortamda yerel halk Suriyeliler ve Suriye hakkında medyanın çeşitli ortamlarında sunulan haberlere ve bilgilere maruz kalmaktadır. Bazı medyanın Türkiye vatandaşları ile Suriyeliler arasındaki uyuma yönelik motive edici içerikler üretmeleri bazılarının da iki ülke insanının yaşadıkları sorunları ortaya koyarak hazırladıkları çok çeşitli bilgiler çeşitli mecralarda sürekli dolaşımdadır. Bu bilgilerin gündelik yaşamda Türk vatandaşlarının sürekli önüne çıkması, Türk vatandaşları nezdinde Suriyeliler ve Suriye ülkesi hakkında 2011 iç savaşı öncesi süreçtekinden daha çok bilgiye ve duyguya sahip olmasına kaynaklık yapmıştır. Böyle bir süreçte Suriye'nin ülke imajına yönelik bir çalışma yapılması araştırmacı tarafından önemli olarak görülmüş̧ür. Bu çalışmada 
Suriye ülke imajına yönelik resimler üzerinden imaj arayışları yapılması amaçlanmıştır.

Buna göre çalışmanın temel araştırma soruları şu şekilde sıralanabilir:

1. Öğrenciler Suriye hakkında sahip oldukları bilgi, fikir, inanç birikimlerini ve duygusal durumlarını resimlerde ifade etmişler midir?

2. Resimlerde Suriye ülke imajını ortaya koyan ortak kavramlar nelerdir?

3. Resimlerde Suriye ülke imajını tanımlamak için hangi cinsiyet ögesi daha çok kullanılmıştır?

4. Öğrencilere göre Suriye imajı nasıldır?

Bu çalışma Suriyeli sığınmacı nüfusu bakımından ciddi bir nüfusa sahip olan Konya kentinde 2019-2020 Akademik yılının Güz döneminde Necmettin Erbakan Üniversitesi Güzel Sanatlar Fakültesi Resim Bölümünde eğitim gören 272 . Sınıf öğrencisi ile gerçekleştirilmiştir. Öğrencilere "Suriye imajlarının ne olduğu? sorulmuştur. Öğrencilerin Suriye hakkında sahip oldukları imajları anlatacak serbest tarzda resimler yapmaları için 1 aylık süre öngörülmüştür. Öğrencilerin çalışmalarından beşi araştırmacı tarafından çalışma kapsamında değerlendirilmek için seçilmiştir. Resimlerin seçimi gerçekleştirilirken Resim Bölümü öğretim üyelerinden 2 uzman görüşüne başvurulmuştur.

Çalışmanın verileri olan resimler analiz edilirken, göstergebilim yönteminden yararlanılmıştır. Gösterge, duyular aracılığıyla kavranabilen, kendileri dışında bir şeye işaret edebilen, böylece işaret ettiği ya da temsili olduğu o şeyin yerine geçebilecek nesne, biçim, olgu vb. şeklinde ifade edilmektedir. Göstergeler, toplumsal dizgeler olup, bireyler arası iletişimi sağlamaktadır. Göstergebilim, bu gösterge dizgelerinin işleyişlerini bilimsel yöntemle çözümlemektedir (Rifat, 2009, s.11-12). Göstergebilimsel çözümleme yönteminde, gösteren ve gösterilen arasındaki ilişki görsellerde düz anlam ve yan anlamı meydana getirmektedir. Yapısal anlamda görsellerin çözümlenmesi de bu şekilde yapılmakta ve izleyicinin görselleri ilk bakışıla algılanmayan yan anlamların çözümlenmesi için izleyicinin öncül bilgileri devreye girmektedir. Gösteren ve gösterilen kavramlarıla ifade edilen iki unsurun bileşimi neticesinde gösterge kavramı oluşur. Gösteren kavramının içinde yer alan imgelerin arka planındaki anlam ve kavramlar kümesi gösterilen kavramını tanımlamaktadır. Gösteren ise imgelerin birlikteliği şeklinde karşılık bulmaktadır (Ertan ve Sancarc1, 2017, s.30-34). Saussure, işaret ve 
bileşenlerinin anlamı nasıl inşa ettiğini parçalara odaklanarak incelemektedir. Bu bakımdan, hakkında çalıştığ dilbilimsel işarete ait iki bileşenden söz eder: gösteren ve gösterilen. Bu işlem formüle yansıtıldığında, gösteren ve gösterilenin toplamının işaret sonucunu (gösteren + gösterilen =işaret) verdiğini değerlendirir. Gösteren, bir işaretin maddi karşılığıdır: bir resim, yazı1 bir kelime ya da sözlü bir ses; gösterilen gönderme yapılan zihinsen görüntüdür (Bate, 2013, s.55). Bir diğer göstergebilimci Charles Sanders Peirce, göstergeyi nesnesi açısından sınıflandırarak üç tür göstergenin varlığını ortaya koyar. Bunlar belirti, görüntüsel gösterge ve simge bu grupta yer alan göstergeleri ifade eder. Belirti insan üretimi olmayan, insan dışında oluşan bir göstergeye karşılık gelir. Ancak diğer ikisi ise insanlar tarafından belirli amaçlara yönelik oluşturulur ve belli bir iletişim ortamında kullanılır. Belirti güneşin ufukta kaybolması ve akşamın olması örneğinde olduğu gibi bir neden sonuç ilişkisi kurar. Görüntüsel gösterge yansıma sesler, görüntüye dayalı bir fotoğraf, resim, bir desen, bir karikatür örneklerinde olduğu gibi nesnesi ile bir benzerlik ilişkisi kurar. Simgede ise, gösterge ile nesnesi arasında saymaca bir ilişki vardır. Gösterge soyut bir anlamla yüklüdür. Batmakta olan bir güneşin birisine yaşlılığı simgeleştirmesi, başka birisi içinde romantizmi simgeleştirmesi örnekleri verilebilir. Ancak bu son durumlar bir uzlaşmaya dayalıdır. Simgeleştirme toplumsal ve bireysel uzlaşıya dayalıdır. Gösterilen her zaman soyuttur. Simge bir tür yorumlama gerektiren iştir (Günay, 2012, s.14-16). Saussure'ün gösteren ve gösterilen arasındaki görüntüsel ilişkiler ve nedensiz ilişkiler diye adlandırdığı şey, Peirce'ün görüntüsel göstergelerine ve simgelerine tam olarak karşllık gelmektedir (Fiske, 2017, s.131). Sonuç olarak bu çalışmada da göstergebilim hakkında literatürde yer verilen açıklamalar doğrultusunda, çalışmanın görselleri gösteren ve gösterilen ilişkisi bağlamında değerlendirilerek yorumlanacaktır. 


\section{Bulgular}

\section{Resmin Künyesi:}

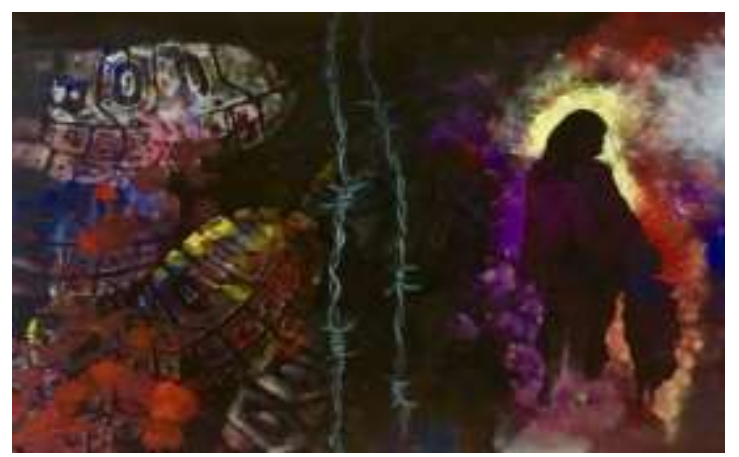

Şekil 1: Öğrenci 1'in Resmi

Sanatçı: Ömer Baran.

Yapım Tarihi: 08 Kasım 2019

Yer: Konya

Üniversite: Necmettin Erbakan Üniversitesi

Fakülte: Güzel Sanatlar Fakültesi

Bölüm: Resim Bölümü

Sinif: 2. Sinif

Gösterenler: Bir kadın; bir çocuk; dikenli teller; asker botları; siyah, gri, kırmızı, mavi, sarı, mor, pembe renkler

Gösterilenler: Üç kesitte değerlendirilen bu fotoğrafın ilk kesitinde asker botlarının taban kısmı dikkat çekmektedir. Asker botlarının alt kısmının izlerinde gri, mavi, sarı ve kırmızı renklerin olduğu görülmektedir. Resmin genelinde kullanılan renklerin anlamları değerlendirildiğinde, gri rengin ciddiyet, askeriye, diplomasi, hareketsizlik ve belirsizlik; mavi rengin sevgi, huzur, güven ve barış; kırmızı rengin hakimiyet, kontrol, gerginlik, saldırganlık, mutluluk; sarı rengin umut ve hüzün; siyah rengin duygusallık, hüzün, güç, otorite; mor rengin güven, sakinlik, itibar ve pembe rengin ise rahatlatıcı, hayaller ve korunma duygusu gibi anlamlara çağrışım yaptığ şeklinde ifade edilmektedir (Gökçe, 2013, s.131-134). Kırmızı ayrıca herkesçe kan rengi olarak bilinir. Aynı şekilde siyah karanlığın sembolü olarak düşünüldüğünde korkunun rengi olarak da ifade edilebilir.

Özgürlügün simgesi olan mavi rengin asker botlarının altında yer almas1, Suriye'deki iç savaşta zulme uğrayan halkın özgürlüğünün çiğnendiğini gösterdiği şeklinde değerlendirilmiştir. Kırmızı rengin botların izlerinde yer 
alması ile bu iç savaşta hayatlarını kaybeden insanlara, mutsuzlaştırılan bir topluma ve insanlara yapılan saldırılara dikkatlerin çekilmek istendiği söylenebilir. Ciddiyet, belirsizlik ve askeri temsilleri olan gri renk ile de savaşın insanlar üzerindeki oluşturduğu belirsizliğe ve askeriyenin rengi olarak savaşın ortaya çıkardığı yıkımların varlığına işaret edildiği belirtilebilir.

İkinci kesitte ise demir teller oldukça dikkat çekicidir. Teller ülkeler arasındaki sınırın en açı sembolüdür. Sanatçı telleri kullanarak savaşın coğrafyası olan Suriye ile barışın, huzurun, umudun olduğu Türkiye arasındaki sınıra çağrışım yapmak istediği söylenebilir. Çünkü teller Özgül'ün de ifadesi ile mülteci krizi ile ilişkili en çok karşılaşılan imgeler arasındadır. Diğer imgeler ise sınır kapıları, yollar, çadırlar, botlar, can yelekleri, kamplar ve çocuklar şeklinde sıralanabilmektedir (Özgül, 2016, s.4). Gri renkli dikenli tellerin siyah bir zemin üzerinde yer veriliyor olması da, ülkeler arasındaki siyasal sınırı oldukça net şekilde ifade ederken siyahın sınır hattında belirginleşmesi sınır hattında göç eden insanların maruz kaldığı hüznü, zorlukları duygusal durumları açıkça ifade ettiği şeklinde değerlendirilmiştir.

Üçüncü kesitte ise mor, oldukça az olmakla birlikte pembe, sarı, kırmızı ve çok az olarak mavi renklerin kullanıldığı bir zemin üzerinde tamamen siyah renkli olarak ifade edilen bir kadın ve kadının elinden tuttuğu bir çocuk resmedilmiştir. Siyah renkli görünümleri ile baştan aşağ hüzün ve duygusal bir hal ile sınırı geçen mülteci kadın ve çocuğunun sınırın öteki yakası olan Türkiye'den beklentisi olan huzur, güven, sakinlik, barış özlemi ve umut mavi, mor ve sarı renklerle sembolize edildiği değerlendirilmiştir. Ayrıca hafif pembe renk ile Türkiye'deki yeni hayata yönelik hayallerin ve korunma duygularının da işlendiğine yönelik çıkarımlar yapılabilmektedir.

Resim 1'in genel değerlendirilmesi yapılacak olduğunda, sanatçı 1'in gözünde Suriye imajı savaş, ölüm, hüzün, belirsizlik, zorluklar, mağdur kadın ve çocuklar, ölüm, hürriyet yoksunluğu, mutsuzluk anlamlarına geldiği şeklinde ifade edilebilir. 


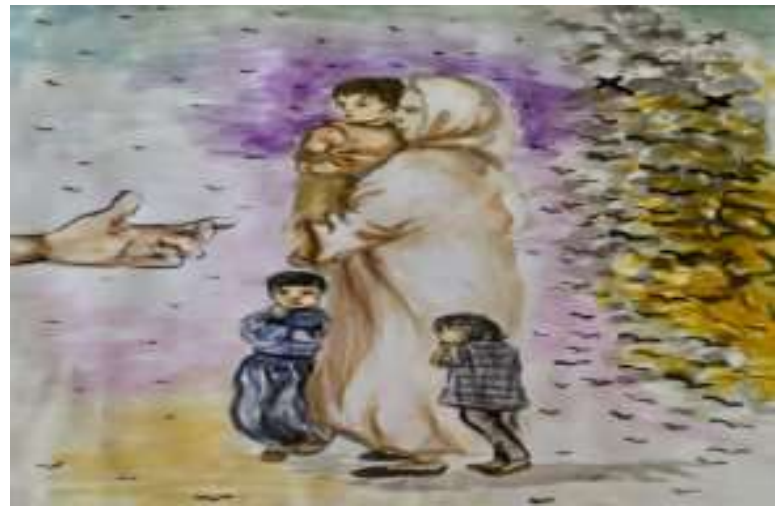

Şekil 2: Öğrenci 2'nin Resmi

\section{Resmin Künyesi:}

Sanatçı: Hatice Soydan

Yapım Tarihi: 08 Kasım 2019

Yer: Konya

Üniversite: Necmettin Erbakan Üniversitesi

Fakülte: Güzel Sanatlar Fakültesi

Bölüm: Resim Bölümü

Sinif: 2. Sinif

Gösterenler: Bir el; üç çocuk; bir kadın; kuşlar; uçaklar ve bulutlar.

Gösterilenler: Üç kesitte değerlendirilmesi yapılan bu resmin ilk kesitinde; kadın ve çocuklara doğru uzanan ve gel işareti yapan bir erkek eli dikkat çekmektedir. İkinci kesitte ise biri kadının kucağında, kahverengi kıyafetiyle ve uzanan ele doğru bakan küçük bir çocuk; yine kahverengi kıyafeti ile anne olan bir kadın resmedilmektedir. Ayrıca üst kıyafeti mavi alt kıyafeti siyah olan, yüzü umutsuzca resmin dışına doğru bakan ve kollarını bağlamış (kavuşturmuş) bir erkek çocuğu ve annesine yaslanarak kulaklarını elleriyle kapayan tamamen siyah giyimli bir küçük erkek çocuğu daha bu kesitte yer almaktadır. Üçüncü kesitte ise siyah renkli kuşların ve uçakların varlığ dikkat çekicidir.

Görsel 2'de tercih edilen renkler incelendiğinde, Görsel 1'de karşılaşılan renklere ek olarak kahverengi renk oldukça dikkat çekici şekilde görülmektedir. Fidan (2012, s.276), kahverengi rengin kıyafetlerde pek tercih edilmediğine ve kahverengi kullanan insanların rahatlık ve güven hissinden uzak olabileceğini değerlendirmektedir ( Fidan; 2012, s.276). 
İlk kesitte yer alan erkek elinin, sınırın umut tarafı olarak görülen Türkiye'yi temsil ettiği değerlendirildiğinde, Türkiye'nin Suriye krizinin başladığı 2011 yılından beri takındığı siyasi tavrının resmi icra eden sanatçının algısına yerleştiği söylenebilir. Çünkü Türkiye Cumhuriyeti'nin, Suriyelilerin can güvenliklerine yönelik uyguladığı "açık kapı politikası" herkes tarafından bilinmektedir (Pirinççi, 2018, s.44). Bu açıdan resimdeki gel işareti yapan el görselinin, Türkiye'nin Suriye'deki krizde mağdur olan insanların güvenilir limanı olmasına bir gönderme olarak değerlendirilmiştir. El görselinin olduğu tarafta uçakların hiç olmaması ve sadece özgürlüğün sembolü olan kuşların resmedilmiş olması da bu değerlendirmeyi pekiştirdiği ifade edilebilir. Özgürlüğün ve güvenin Türkiye'de olduğu söyleminin resmin bu kesitinde yer bulduğu bu bakımdan açıktır.

Suriye algısına yönelik ikinci kesit önemli okumalara olanak tanımaktadır. Rahatlık ve güven yoksunluğunun bir ifadesi olarak ifade edilen kahverengi tonlarının kadın ve kucaktaki çocuk görsellerinde tercih edilmiş olmaSı sanatçının zihninde Suriye'nin güvensiz ve konforsuz bir ülke olduğuna yönelik oluşan güçlü imajın ifadesidir. Kucaktaki çocuğun ve kadının yüzünün "ele" doğru bakması ise, güven ve rahatın Türkiye'de olduğu çağr1şımlarını işaretlemektedir. Üst kıyafeti mavi ve alt kıyafeti siyah olan, kollarını (kavuşturup) bağdaştırıp resmin dışına doğru bakan küçük çocuk ise, belirsizliğin, huzursuzluğun, duygusallığın ve hüznün çağrışımlarını yapmaktadır. Kol kavuşturma hareketi kişinin kendini güvende hissetmediğinin bir ifadesi olarak yorumlanmaktadır (Pease, 1988, s .59). Böylece çocuğun kendini güvende hissetmediği anlamı pekiştirilmiştir. Siyahlar içinde kulaklarını kapayarak annesine sarılan çocuk görseli korku, hüzün ve güven yoksunluğunu ifade ettiği şeklinde değerlendirilebilir. Üzerlerinde uçan uçakların ve savaşın seslerine tanıklık etmenin çocuk üzerindeki etkilerini açıkça ifade eden bu görselde, sanatçının zihnindeki Suriye algısında korku, hüzün ve güvensizlik kavramları da kolayca anlaşılmaktadır. Anne ve çocuklarının üzerlerinde yer alan mor bulutlar ise mor rengin çağrışımlarını yaptığı anlamlar çerçevesinde, ele doğru devam eden yürüyüş̧lerinin güven ve sükûnetle sonuç bulacağını anlattığı şeklinde değerlendirilebilir.

Üçüncü kesitte yer alan kahverengi ve siyah renkli zemin üzerinde resmedilen ve genelde özgürlük çağrışımı yaptığı düşünülen kuşlar ile bu resim için savaşın sembolü olarak düşünebilecek olan uçaklar ise özgürlük ve hürriyet yoksunluğu gibi iki karşıt kavramı bir arada düşünmeye sevk et- 
mektedir. Ayrıca kuş sembolünün Türklerdeki algısı Gök Tanrı idaresindeki bir varlık olduğu yönünde değerlendirilmektedir. Bundan dolayı kuşlar insana iyilik sağlayan bir uğur anlamıla çağrışım kazanmaktadır. Şamanizm inancı bağlamında ise ölen birinin ruhu olarak da değerlendirilmektedir. Ölen kişilerin ruhlarının bir kuş olarak göğe uçmaları, Türklerde oldukça yaygın bir inanış olduğu ifade edilmektedir (Sever, 1999, s.86). Şişci (2018, s.52) de çalışmasında kuşun tutsaklık, özgürlük ya da umudun çağrışımlarına karşllık geldiğini değerlendirmektedir. Bu açıdan Türk öğrenci gözünden kuşların Suriye'deki savaşta ölen insanlara karşlık gelebileceği, bir diğer ifadeyle kuşların ölümün sembolü olarak görüldüğ̈̈ ifade edilebilir. Ayrıca Türkiye tarafında kuşların olması ise, Suriye'den Türkiye'ye doğru yapılan göçten beklenilen umuda yönelik bir anlam çıarılabilir.

Resim 2'nin genel bir değerlendirilmesi yapıldığında, sanatçı 2'nin gözünde Suriye imajı ölüm, tutsaklık, güvensiz, belirsizlik, huzursuzluk, hüzün, korku anlamlarına geldiği şeklinde ifade edilebilir.

\section{Resmin Künyesi:}

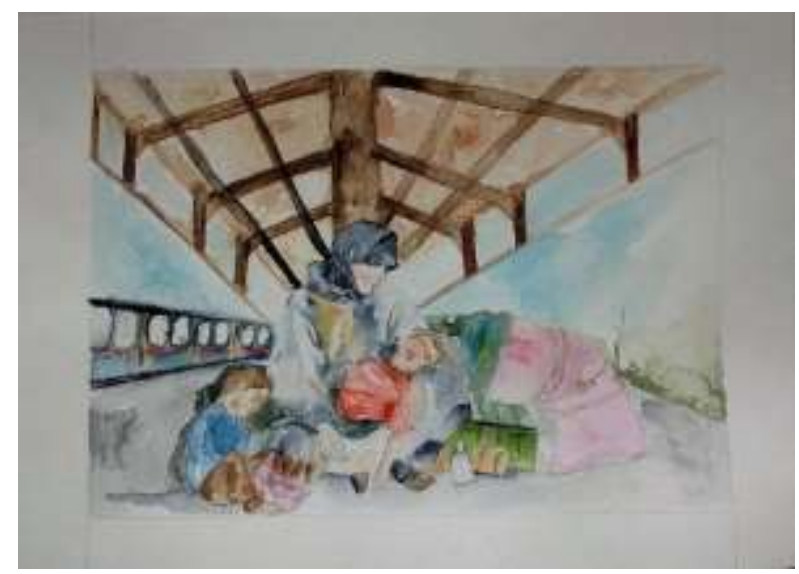

Şekil 3. Öğrenci 3'ün Resmi

Sanatç: Eda Elmas Öcal

Yapım Tarihi: 11 Kasım 2019

Yer: Konya

Üniversite: Necmettin Erbakan Üniversitesi

Fakülte: Güzel Sanatlar Fakültesi

Bölüm: Resim Bölümü

Sinıf: 2. Sinıf 
Gösterenler: Kadın, bebek, çocuk, valiz, eşya çuvalı, biberon, yarım bir ekmek, tren, tren garı

Gösterilenler: Resim 3'ün değerlendirilmesi yapılırken araştırmacı tarafından altı kesitin resimde olduğu belirlenmiştir. Buna göre; ilk kesitte siyah, mavi, sarı ve kırmızı renklerin olduğu bir tren görseli, ikinci kesitte kahverengi renkli tren istasyonunun yolcu peronu, üçüncü kesitte mavi gökyüzü resmedilmiştir. Dördüncü kesitte yeşil bir doğa, beşinci kesitte anne olan bir kadın ve çocukları ve son olarak altınc kesitte ise yeşil bir valiz, kahverengi iple sıkıca bağlanmış pembe ve yeşil renkli eşya çuvalı, yarım bir ekmek somunu ve bebek biberonu yer almaktadır.

İlk kesitte sanatın birçok türüne ilham kaynağı olan tren değerlendirilmektir. Sönmez (2016, s.1155) trenin ölüm ve umudun metaforu olduğunu, çaresizlik dolu göç öykülerinin sembolü olduğunu, istasyonların ise yolcuların üzerini yorgan gibi örttüğünü, yolcuların yoksunlukların, yoksulluklarını, hüzün, sevinç ve umutlarını sembolize ettiğini ifade etmektedir. Yıldırım ise (2014, s.1157) Orhan Veli'nin "Tren Sesi" isimli şiirine yönelik yaptığı bir değerlendirmede de Şairin trenleri yalnızlı̆̆ın, çaresizliğin, uzaklarda kalmışlığın, eş ve dosttan ayrılmanın sebebi olarak gösterdiğini yorumlamaktadır. Tren görselinde siyah renk ağırlıklı olsa da mavi, sarı ve kırmızı renklerinin birleşiminin trenin neredeyse yarısında yer aldığı görülmektedir. Buradan hareketle özlemlerin, çaresizliğin, ölümün, ümitsizliğin sembolü olan "kara tren"in, mavi, sarı ve kırmızı renklerle görselleştirilmesi ile olumsuz tüm alg1 ve düşüncelerin olumluya çevrilme çabası da açıkça çözümlenebilir. Böylece Suriye'deki savaşın göçe zorladığı masum insanlar üzerinde oluşan ölüm, çaresizlik, gurbet ve hüzün gibi olumsuz duygu ve durumların, gerçekleşen göç yolculuğu ile belki sona erebileceği ya da göçülen mekanda daha olumlu şartlarda yaşanabileceği umudu ve sevinci görselleştirilmiştir. Huzur, güven ve barışın çağrışımlarını yapan mavi, mutluluğun ifadesi olarak kırmızı ve umut anlamına gelen sarı renklerin tren görselinde tercih ediliyor olması da bu anlamı desteklemektedir.

İkinci kesitte ise kahverengi renkle ifade edilen tren garının yolcu peronunun çatısı dikkat çekicidir. Kahverengi renk rahatlık ve güven hissinden uzak olan, toplumsal anlayışa gerek duyan insanın rengidir. Ayrıca kaybolmanın ve saklanmanın rengi olarak da karşılık bulmaktadır (Fidan, 2012, s.276). Bu açıdan, savaşın göç edenler üzerinde yarattığı rahatsızlık ve güvensizlik duyguları ile yeni bir mekana gelen Suriyeli göçmenlerin geldikle- 
ri yerden beklenti içinde oldukları toplumsal anlayışına yönelik bir değerlendirme yapılabilir.

Üçüncü kesitte sanatçının gökyüzünü mavi olarak betimlediği görülmektedir. Dünyanın hemen hemen her kültüründe güvenin rengi olarak mavi tercih edilmektedir. Savaşla birlikte sevginin, huzurun, güvenin ve barışın da yok edildiği bir ülkeden yeni umutlara doğru bir göç gerçekleşmektedir. Savaşla birlikte kaybedilen olumlu duyguların tekrar kazanma şansının olabileceği, yeni bir hayatın yaşanılacağı yeni ülkenin gökyüzü ise mavi ile renklendirilerek resmedilmiştir. Olumlu çağrışımların kaynağı olan mavinin renklendirme de kullanılması ise mesajı pekiştirmektedir. Böylece göç eden bireylerin yeni yerde sevgi, huzur, güven ve barış gibi yoksun kaldıkları olumlu duygu ve durumlarla karşılaşabilecekleri anlamı ifade edilebilir. Göç sakin, rahat, daha iyi ve konforlu bir hayatın arayışına karşılik gelmektedir. Batur'un (2016, s.281) mavi rengin birey üzerindeki etkisini ifade ederken kullandığı sakinleştirici ve rahatlatıcı olma özellikleriyle çok çeşitli kültürlerde güvenin rengi olarak mavinin tercih ediliyor olması (2011, Mazlum, s.133) da bu anlamda yapılan yorumları destekler niteliktedir.

Dördüncü kesitte ise az da olsa yeşil bir doğa manzarası resmedilmiştir. Batur (2016, s.7) yeşil rengin yaşamı simgelediğini ifade eder. Aynı zamanda yeşil baharın, canlılığın ve olumlu dinginliğin rengidir (Mazlum, 2011, s.133). Bu anlamda değerlendirildiğinde, ölümün coğrafyası olan Suriye'den yaşama doğru gerçekleşen bir göçün anlatımında kısmen de olsa yeşil kullanımı algı bağlamında zihinlerde yaşam ve ölüm arasındaki ikileme çağr1şım yapmaktadır. Suriye'deki savaşın her çeşit kaos ve kargaşasından göçerek uzaklaşma çabasındaki insanın aradığı dinginliğin ifadesi olarak da değerlendirilebilir.

Beşinci kesitte siyah başörtüsü ve gri tonlarındaki elbisesi ile mavi, kırmızı, siyah ve kahverengi tonlarında kıyafetleri olan iki çocuk resmedilmiştir. İnsanların yüzlerindeki savaşın acıları ve yorgunlukları rahatlıkla görülmektedir. Kırmızı ve mavi renkleriyle çocukların üst kıyafetleri yaşanılan gerginlikle birlikte, huzur, güven ve mutluluk arayışındaki göç yolculuğuna çağrışım yapmakta olduğu değerlendirilmiştir. Annenin siyah başörtüsü hüznü ve duygusallığı ifade etmesi bakımından oldukça açık mesajlar vermektedir. Ayrıca annenin kıyafetindeki gri ise hali hazırda göç hissiyatının yarattı̆̆ belirsizliğe çağrışım yapmaktadır. Çocukların alt kıyafetlerinde kullanılan kahverengi ve siyah renkler önceki çözümlemelerde de ifade 
edildiği üzere, güven yoksunluğunun ve içinde bulunulan durumdan kaynaklanan rahatsızlığın ve hüznün çağrışımlarını yaptığı yönünde değerlendirilebilir.

Resim üçün son kesitlemesi olan altınc kesitte yeşil bir valiz, kahverengi iple sıkıca bağlanmış pembe ve yeşil renkli eşya çuvalı, yarım bir ekmek somunu ve bir bebek biberonu resmedilmiştir. Resmin bu kesitindeki valiz ve eşya çuvalı göç ve yolculuk kavramlarına doğruda çağrışım yapmaktadır. Tahta bavul olarak da adlandırılabilen ahşap bir valiz ile eşya çuvalının resmedilmesi ise yaşanan yoksulluğun en açık ifadesi olarak değerlendirilebilir. Savaşın ürettiği yoksulluğun en belirgin yanı olarak görülmekle birlikte, bu ahşap valiz ve eşya çuvalının renklerindeki anlam ise umuda yönelik güçlü çağrışımları da beraberinde getirmektedir. Pembe eşya çuvalı hayalleri, yeşil ahşap valiz ise güven, huzur ve rahatlığa doğru yapılan göçü ifade etmesi bakımından değerlendirilebilir. Valiz ve eşya çuvalı geride kalanlara da işaret etmesi bakımından özlem duygusunu ve ancak sığabildiği kadarıyla alınan eşyalar bağlamında da düşünüldüğünde de sahip olunan sınırlllığı da tanımladığı değerlendirilebilir. Biberon'un ve yarım ekmeğin resmedilmesi ise, her şeye rağmen hayata tutunmanın gayretini gösterdiği ifade edilebilir.

\section{Resmin Künyesi:}

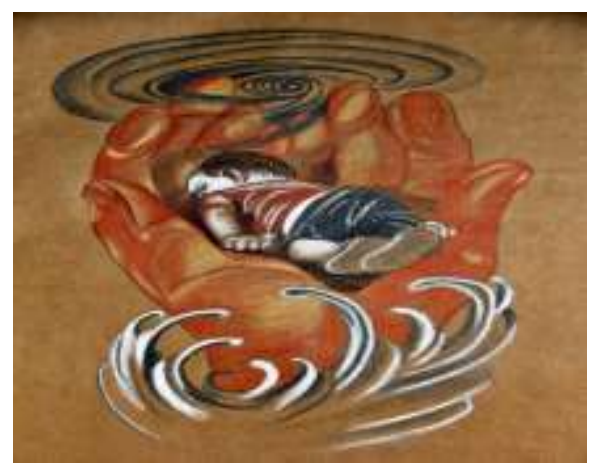

Şekil 4: Öğrenci 4'üin Resmi

Sanatç: Hatice Atun

Yapım Tarihi: 24 Kasım 2019

Yer: Konya

Üniversite: Necmettin Erbakan Üniversitesi

Fakülte: Güzel Sanatlar Fakültesi

Bölüm: Resim Bölümü

Sinif: 2. Sinif 
Gösterenler: İki el, bir çocuk.

Gösterilenler: İki kesitte değerlendirilmeye çalışılan Resim 4'te birinci kesit olarak Suriye savaşının sembolü haline gelen Aylan Bebek ve ikinci kesitte ise iki elin birleşiminden oluşan bir avuç görülmektedir. Aylan Bebek 2015 yılında batan bir mülteci botunda hayatını kaybetmiş ve cansız bedeni Muğla'nın Bodrum ilçesinde sahile vurmuştur. Kıyıya vuran bu cansız beden, dünya insanlığını derinden etkilemiştir. Sanatçıda bu resimde savaşın en çok ölüm anlamına geldiğini açkça ortaya koymaktadır. Savaşın yaş ve cinsiyet fark etmeden insanlığın yıkımına sebep olan bir olgu olduğu gerçeği bu görselde vurgulanmaktadır. Aylan bebeğin üzerindeki tişört rengi olan kırmızı ailesiyle birlikte yoluna düştükleri mutluluk arayışının sembolü iken, yaşanan hadise ile ölüm, göç, savaş, sığınmacilık ve mültecilik kavramlarının çağrışımını yapacak renkler arasına girdiği ifade edilebilir. Turuncunun anlamsal çağrışımının afetlerde kurtarıcılara atfedildiği ve canlılığın rengi olduğu değerlendirilmektedir (Fidan, 2012, s.277). Ayrıca teknik olarak tehlikeli alanların varlığına bir işaret olarak da kullanıldığ 1 da ifade edilmektedir (Çağlar, 2012, s.31). Bu çağrışımları ile düşünüldüğünde turuncu avuç ile Aylanın cansız bedenini ellerine alan bir bireyin resmedilmesi başka Aylan bebeklerin bu şekilde ölmemesine yönelik bir çağrışıma işaret olarak değerlendirilmiştir. Bu görselle, insanların Aylan bebeklere ve onlar gibi olan her yaştan ve ırktan savaşın ve zulmün acı süreçlerine tanıklık edenlere karşı duyarlı olmaları hususunda bir çağrı yapıldığı da belirtilebilir. Tehlikenin de kurtarıcılığında sembolü olarak turuncu renk ile insanlığın kaderini yine insanın kendi eliyle olumlu ya da daha olumsuz sonuçlara doğru yön verilebileceği anlamları da değerlendirilebilir. 


\section{Resmin Künyesi:}

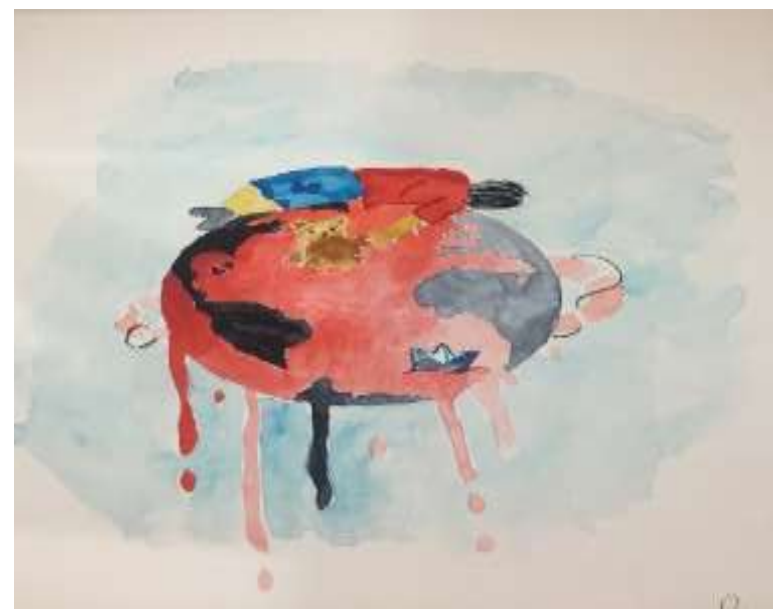

Şekil 5. Öğrenci 5'in Resmi

Sanatçı: Gamze Çuhadar

Yapım Tarihi: 10 Kasım 2019

Yer: Konya

Üniversite: Necmettin Erbakan Üniversitesi

Fakülte: Güzel Sanatlar Fakültesi

Bölüm: Resim Bölümü

Sinif: 2. Sinif

Gösterenler: Dünya, bir çocuk, bir oyuncak ayı, kağıt gemi.

Gösterilenler: İki kesitte değerlendirilen Görsel 5'in ilk kesitinde izleyicinin dikkatini doğrudan çeken dünya üzerinde bir çocuk ve elinde oyuncak ayısı, ikinci kesitte ise kırmızı ve siyah renklerin kullanılarak resmedildiği dünya vardır. Barışa, güvene, huzura doğru yapılan yolculuğun sembolü olan Aylan Bebek bu resimde mavi ve kırmızı renkli kıyafetlerle resmedilmiştir. İkinci kesitte ise yaşanan bot faciasında hayatını kaybeden Aylan bebeğin ahının tüm dünya üzerine yüklendiği sanatçı tarafından resmedilmek istendiği değerlendirilmiştir. Elindeki oyuncak ayısıyla yaşanan hiçbir hadiseden ve etrafındaki zulümden haberi olmayan bir bebeğin derin masumiyetini ve onun nezdinde diğer tüm mağdur coğrafyalardaki çeşitli zulümlere maruz kalan insanlığın hali rahatlıkla resimde anlatılmak istendiği değerlendirilebilir. Dünyanın üzerine bulaşan vahşetin sembolü olarak kırmızı kan rengi de Suriye'de yaşanan savaş ve dünyanın diğer yerlerindeki savaşların acısını anlatmaktadır. Dünyanın bir bölümünün de siyah renkle 
resmedilmesi ise acıların ve hüznün coğrafyalarını anlatması bakımından duygusallık içerdiği değerlendirilebilir. Ayrıca dünyanın üzerinde resmedilen diğer bir obje ise kağıt gemidir. Çocukların yaşanılabilir bir dünyada ve ortamda elinde oyuncak gemisiyle evinde ya da kapısının önünde güvenle kağıt gemisini yüzdürmesi çocukluğun gereği olarak bilinen ve beklenen bir eğlenme ve oyundur. Güven ortamında kağıt gemisiyle yuvasında oyun oynayacakken, zorunlu göçe zorlanarak bir botla ölüme doğru yapılan yolculuğun okuması yapılabilmektedir. Göçmen botlarının kırmızı denizlerde yolculuğu, neredeyse kasıtlı olarak ölüme doğru yapılan bir yolculuğu anlatması da açıkça değerlendirilebilir. Dünyanın üzerinden siyah ve kırmızı renkle damlayan görseller ise dünyanın hemen her yerinde aciların ve kanın gözyaşlarına karıştı̆̆ını işaretlediği ifade edilebilir.

\section{Tartışma ve Sonuç}

Bu çalışma doğrudan Suriye imajına yönelik yapılan ilk çalışma olması bakımından değerli görülmektedir.

Çalışmaya katılan öğrencilerin resimlerinde Suriye hakkında sahip oldukları bilgi, fikir ve inanç birikimlerini ve duygusal durumlarını resimlerinde ifade ettikleri değerlendirilmiştir. Çalışmada çözümlemesi yapılan eserler değerlendirildiğinde, öğrencilerin Suriye iç savaşını komşu ve göç edilen ülke insanı olarak oldukça önemsedikleri ve Suriye imajlarının şekillenmesinde ise savaş durumunun oldukça etkili olduğu ifade edilebilir. Çünkü resimlerde savaş mağduru ve savaş sonrası göçe zorunlu kalan insanların durumları anlatılmaktadır. Savaşın sembolleri arasında yer alan asker botlarının, savaş uçaklarının, sınırları belirleyen dikenli tellerin, göçün akla getirdiği tren istasyonu ve tren, göç yolculuğundaki insanlar ve onların yaşadıkları duygusal durumları resimlerde anlatılmaktadır.

Resimlerde Suriye imajını ortaya koyan ortak kavramlar ise; savaş, ölüm, hüzün, belirsizlik, zorluklar, mağdur kadınlar, mağdur çocuklar, hürriyet yoksunluğu, mutsuzluk, tutsaklık, güvensiz ortam, huzursuzluk, korku, şiddet, çaresizlik, umutsuzluk, kaos, acı, sevgisizlik, göç, yoksulluk, imkansızlık, kan, zulüm ve tehlike olarak sıralanmıştır.

Resimlerde Suriye imajının kadın cinsiyeti üzerinden vurgulandığı da ayrı bir bulgu olarak ifade edilmelidir. Savaş durumunun olduğu Suriye 
coğrafyasında kadınların ve yanlarındaki çocukların mağduriyetleri resimlerde özellikle dikkat çeken ögeler arasındadır.

Suriye imajının medyadan etkilendiği de ifade edilebilir. Öğrencilerin hem sosyal medya ortamların kullandıkları hem de televizyon ve gazete gibi yazılı ve görsel medya araçlarını takip ettikleri öngörüsü ile öğrencilerin Suriye hakkında oluşturdukları algiların medyadan etkilendiği değerlendirilebilir.

Resimlerin tümünde Suriye imajının olumsuz olduğu değerlendirmesi yapılmıştır. Bu makul ve beklenen bir bulgudur. Sadece savaş ve savaş sürecinde gerçekleşen göç bilgi ve haberleri ile sürekli karşılaşan öğrencilerin zihninde Suriye imajının olumsuz olarak karşılık bulması oldukça normal bir sonuçtur.

Suriye'nin 2011'den beri yaşamakta olduğu politik sorunlar ve iç savaş durumu, ülkenin uluslararası ortamlarda Suriye'nin sürekli savaşla ilişkilendirilmesine neden olmaktadır. Bu açıdan değerlendirildiğinde Suriye'nin ülke imajının ülkenin politik istikrarsızlığından etkilendiği de ifade edilebilir.

Suriye imajının olumsuz olarak ifade edilmesinde, şüphesiz en önemli neden çalışmanın yaşanan iç savaş ve sonrası süreçte gerçekleştirilmiş olmasıdır. Türk insanının gözünde Suriye imajina dair önceden yapılmış bir çalışmanın olmayışı, savaş öncesi ve sonrası süreçte Türk insanında Suriye imajının karşılaştırılmasını imkansız hale getirmektedir. Ancak savaşın koşullarının barış ortamına dönüşmesi, Suriye'nin yeniden yaşanılabilir bir coğrafya haline gelmesi ile Suriye hakkında uluslararası medya ortamlarında yer alacak olumlu haberler ile Suriye imajının yeni yapılacak çalışmalarda farklı ve olumlu imajlarının ortaya çıkması muhtemeldir.

Özetle, bulgular değerlendirildiğinde, Suriyeli algısına yönelik yapılan çalışmalarda Suriyeli sığınmacılara yönelik Türk halkında var olan olumsuz algının, Suriye ülke imajında da olumsuz olarak ortaya çıması beklenen bir sonuç olarak ifade edilmelidir. Fakat Suriyelilere yönelik oluşan olumsuz algilarla Suriye'nin ülke imajına yönelik oluşan olumsuz algılar arasında bağlam farklılıkların olduğunu da ifade etmek gerekir. Bir tarafta araştırmaların işaret ettiği şekilde başlıca uyum sorunlarından ve ekonomik nedenlere bağlanan Türkiye'nin iç meselesi haline dönüşen bir Suriye sorununun halk üzerinde yansıması olan olumsuz Suriyeli algısı varken, diğer tarafta Suriye devletinin halkına yönelik tutunduğu sert ve ölümcül politik tavırla- 
rın neticesinde ortaya çıan Suriye'nin tüm dünyadaki imajını etkileyen olumsuz bir ülke imajı vardır. Bu noktada Suriyelilerin Türk halkı nezdindeki imajının neden olumsuz olduğuna yönelik literatürde ortaya konan çalışmalar yetkililerin yürütmekte olduğu politikalara şekil verebilecektir. Ancak bu çalışma ile sözün ve sonucun ulaşacağı yer Suriye ülke imajinın hemen yan komşusu olan Türkiye Cumhuriyeti vatandaşları nezdinden bu derece olumsuz şekilde algılanmasına zemin hazırlayan Suriye hükümetinin Suriye ülke imajını, savaş ülkesinden barış ülkesine dönüştürmesi zorunluluğu bu çalışma ile de vurgulanması bakımından önemlidir. 


\section{EXTENDED ABSTRACT}

\section{A Semiotic Study On Syria Image in the Eyes of Turkish University Students

\author{
Salih Gürbüz \\ Necmettin Erbakan University
}

Today, country images like corporations are very important in the eyes of public. In a globalizing world, all countries might compete with each other and produce common policies together. Especially the internal developments of the countries and the positive and negative events experienced with other countries might affect the formation of various images about that country all over the world. The media has an important role in the formation of these images.

Owing to media, humanity have come closer to each other and have more information about each other. Those informations would affect people's some plan on their lives such as people's desire to travel to other countries, to live in those countries, to benefit from the health and education opportunities of those countries. Those can be listed as some of the encouraging factors for individuals to have information about countries other than their own.

Country images are difficult to create, manage and protect, just like corporate and personal images. However, it is also easy to be destroyed the images of the country and turn them into negative, depending on the instantaneous events. Especially the developments that threaten the countries such as crises threatening the institutions can harm the images of the countries. Economic crises, unemployment, health and education problems of today's countries can cause the public to protest the policies of the governments. Various actions such as Arab Spring and American Spring, "protests of yellow vests" in France, Joker protests that took place in various countries from Chile to Jordan were followed through media. In fact, individuals from various countries have discussed their thoughts on these protests on social media as if they were the issues of their own country. The fact that citizens of different countries follow the developments occurring in many different countries of the world so closely can be expressed as a sign of how impor- 
tant the management of the country's images is. It can be stated that the follow-up of such actions by the Turkish public also affects the formation of various images among Turkish people about those countries. Due to such protests taking place in other countries, many countries' governments warn to their citizens not to travel to their country of action. All of these can have a negative impact on individuals' images about other countries.

Managing the images of the country is a very important issue for the purpose of the countries to have opportunities in a wide range of fields, especially in the economy, in international environments. In this study, it was aimed to evaluate the image of the Syrian country. With the Syrian civil war that has started in the spring of 2011 and the immigration events that have followed, in many countries researchers have studied on various subjects about Syria, and the Syrian civil war has also become a civil issue of many countries. Since Turkey has the longest border with Syria, various geographic and historical links, the Syrian civil war has been more on the agenda of the Turkish people than other countries'. Because the majority of Syrian refugees have arrived to Turkey, Turkish people faced with a wide variety of problems such as cultural, economic etc. caused by this migration. It is possible to meet Syrian refugees living in almost every city and district or even in villages in some regions. Each Syrian refugee carries with it a wide variety of elements that make up the culture of its own country, along with its migration. For these reasons, researchers have been studying on Syria and Syrians. Thus, many types of academic publications from various disciplines about Syrian refugees are also revealed.

In terms of public relations, there have been some studies on the Syrian image, but it is remarkable that they are very limited. It should be stated as a separate assessment that the studies on the image of the Syrian are carried out through questionnaires, which are quantitative data collection methods, and through interview forms from qualitative methods. However, this study aimed to focus on Syrian country image. It is important to state that there are no researches on Syrian country image both before and after the civil war in Turkish Public relations academic discipline. With this study, the image of the country of Syria will be researched in the eyes of Turkish participants who live together with Syrian refugees in their daily life. 
The main argument of this study is the idea that artistic works can provide data in reaching scientific results. For this purpose, the study was designed with undergraduate students of the Department of Painting. The students' paintings as the data of this study were analyzed with semiotic analysis. As a result of the study, Syrian image were evaluated with the terms as war, death, sadness, uncertainty, difficulties, victimized women, victimized children, unhappiness, captivity, insecure country, uneasiness, fear, violence, helplessness, hopelessness, chaos, pain, migration, poverty, physical and financial impossibility, blood, cruelty and danger.

\section{Kaynakça / References}

Aslan, A., Cambaz, H. Z. ve Karasu, S. (2018). Üniversite öğrencilerinin suriyeli mültecilere yönelik alg1 ve görüşlerine yönelik bir nitel araştırma. RES Research Studies Anatolia Journal, 1(3), 472-489.

Bakan, Ö. ve Tabakçı, N. (2008). Türk üniversite öğrencileri gözünde rusya imaj.. Selçuk İletişim, 5 (3), 97-110.

Bakan, Ö. (2013). The image of Turkey in the eyes of Dutch university students. Selçuk Üniversitesi Türkiyat Araştırmaları Dergisi, (33), 265-281.

Baloglu, S. ve McCleary, K. W. (1999). A model of destination image formation. Annals of tourism research, 26(4), 868-897.

Batur Çay, M (2016a). Şeref Ruhi Aydın resimlerindeki semboller üzerine bir inceleme. İnönü Üniversitesi Sanat Ve Tasarım Dergisi, 6(14), 1-10.

Batur, M. (2016b). Huzurun rengi mavi. İnönü Üniversitesi Sanat Ve Tasarm Dergisi, 6(13). 279-292.

Bate, David (2013). Fotoğraf anahtar kavramlar. (B. Şimşek, Çev.). Ankara: De Ki Basım Yayım.

Beerli Palacio, A., Díaz Meneses, G. ve Pérez Pérez, P. J. (2002). The configuration of the university image and its relationship with the satisfaction of students. Journal of Educational administration, 40(5), 486-505.

Castro, C. B., Armario, E. M. ve Ruiz, D. M. (2007). The influence of market heterogeneity on the relationship between a destination's image and tourists' future behaviour. Tourism management, 28(1), 175-187.

Çağan, K. (2006). Sanat sosyolojisinin imkânına ve inşasına dair. Bilgi Sosyal Bilimler Dergisi, 2, 11-31.

Çağlar, B. (2012). Bir iletişim biçimi olarak göstergebilim. LAÜ Sosyal Bilimler Dergisi, 3(2), 22-34. 
Çiftçi, H. (2018). Türkiye Cumhuriyeti vatandaşlarının Suriyeli sığınmacılara yönelik tutum, alg1 ve empatik eğilimlerinin analizi. Itobiad: Journal Of The Human \& Social Science Researches, 7(3), 2232-2256.

Çimen, L. K. ve Quadir, S. E. (2018). Üniversite öğrencilerinin Suriyeli sığınmac1larla ilgili tutumlarının sivil katılımları bağlamında incelenmesi. İnsan Ve Toplum Bilimleri Araştırmalan Dergisi, 7(2), 1251-1273.

Ergin, H. (2016). Turkish university students' Perceptions towards their Syrian classmates. Egitim ve Bilim, 41(184), 399-415.

Ertan, G. ve Sansarc1, E. (2017). Görsel sanatlarda anlam ve algı. İstanbul: AlternatifYayınclik.

Erinç, M. S. (2013). Sanat sosyolojisine giriş. Ankara: Ütopya Yayınevi.

Fidan, M. (2012). Illetişim kurmak istiyorum. Konya: Tablet.

Fiske, J. (2017). İletişim çalışmalarına giriş (S. İrvan, Çev.). Ankara: Pharmakon. (Orijinal eserin yayın tarihi 1982)

Gökçe, O. (2013). Iletişim nasıl daha iyi anlar ve anlaşllırım (2.bs.). Konya: Çizgi.

Gülyaşar, M. (2017). Suriyeliler ve vatandaşlık: Yerel halk ve Suriyeli sığınmacılar çerçevesinde bir değerlendirme. Uluslararası Toplum Araştırmaları Dergisi, 7(13), 678-705.

Günay, V.D. (2012). Görsel göstergebilim ve imgenin anlamlandırılması. V.D. Günay, A.F. Parsa (Der.) Görsel Göstergebilim: İmgenin Anlamlandırılması içinde. İstanbul: Es Yayınları.

Kemik, P., Gözübüyük, M. ve Sever, M. (2019). Suriyeli Sığınmacıların Yoğun Yaşadığı Bölgelerdeki Yerel Halkın Suriyeli Sığınmacılara İlişkin Görüşleri: Altındağ Örneği. Mukaddime, 10(2), 582-596.

Linkemer, B. (1997). Profesyonel imaj yaratmak. İstanbul: Rota Yayınları.

Martínez, S. C. ve Alvarez, M. D. (2010). Country versus destination image in a developing country. Journal of Travel \& Tourism Marketing, 27(7), 748764.

Mazlum, Ö . (2011). Rengin kültürel çağrışımları. Dumlupınar Üniversitesi Sosyal Bilimler Dergisi, 31, xxx-xxx.

Özgül, G . (2016). Sınır kapıları, dikenli teller, yollar, kamplar ve çocuklar: Kurban ve istisna olarak muilteci. Marmara İletişim Dergisi, 25, 1-16.

Pease, A. (1988) Body language: How to read others' thoughts by their gestures. London: Sheldon Press.

Peltekoğlu, F.B. (2014). Halkla ilişkiler nedir?. İstanbul: Beta.

Pirinççi, F. (2018). Suriye'ye komşu ülkelerin Suriyeli mültecilere yönelik politikaları. Tesam Akademi, 5(2), 39-60. 
Polat, F. Ç. Ve Kaya, E. (2017). Bir ötekileştirme pratiği: Türkiye'de yaşayan Suriyelilere yönelik tutumlar. Mersin Üniversitesi Sosyal Bilimler Enstitüsü Dergisi, 1(1), 38-48.

Rifat, M. (2009). Göstergebilimin ABC'si. İstanbul: Say Yayınları.

Sağır, A. Ve Kurtkara, S. (2018). Sosyoloji bölümü öğrencilerinin" Suriyeli" kavramına ilişkin tutumları üzerine sosyolojik bir çözümleme:Bülent Ecevit Üniversitesi ve Karabük Üniversitesi örneği. Journal Of International Social Research, 11(60), 648-661.

Sever, M. (1999). Türk mitolojisinde kuşlar. Milli Folklor, 42, 83-88.

Şişci, F. (2018). Türk mitolojisinde güvercin motifi ve çağdaş Türk resminde temsili. İil Sanat Ve Dil Dergisi, 7(41), 47-53.

Sönmez, M. Ve Adıgüzel, F. (2017). Türkiye'de Suriyeli sığınmacı algısı: Gaziantep Şehri örneği. Gaziantep University Journal Of Social Sciences, 16(3), 797-807.

Şen, G. ve Şimşek, H. (2019). Türkiye'deki kamu yönetimi öğrencilerinin Suriyeli sığınmacılara ilişkin tutumları. Manas Sosyal Araștırmalar Dergisi, 8(2), 1958-1974.

Yazıcı, İ. (1997). Kitte iletişimde imaj kuramsal bir yaklaşım. İstanbul: Bilim yayınlar1.

Yıldırım, A. (2014). Edebiyat ve kültürümüzde tren. Electronic Turkish Studies, 9(6). 1153-1161.

Yuille, J.C. and Catchpole, M.J. (1977). The role of imagery in models of cognition. Journal of Mental Imagery, 1,171-180.

Vural, Z. B. A. ve Bat, M. (2013). Teoriden pratiğge kurumsal iletişim. İstanbul: İletişim yayınları.

\section{Kaynakça Bilgisi / Citation Information}

Gürbüz, S. (2020). Türk üniversite öğrencileri gözünde Suriye imajı üzerine göstergebilimsel bir çalışma. OPUS-Uluslararası Toplum Araştırmaları Dergisi, 15(26), 3988-4018. DOI: 10.26466/opus.662744 